more cohesively the research programmes it is responsible for. Already there are some signs that the divisions between disciplines which the council inherited have softened, although the establishment of separate committees to serve the separate arms of the council's activities is bound to preserve some of the distinctions.

The council is responsible for research in the United Kingdom which is concerned with the environment. This covers geology, oceanography, the Nature Conservancy, the Antaretic Survey, hydrology and forestry, and each of these broad areas has been provided with an advisory committee to establish policy and make recommendations about grants. The total income of the council over the year was just over $£ 5 \frac{1}{4}$ million: the table shows how this income was distributed among the competing interests:

Institute of Geological Sciences Nature Conservancy

National Institute of Oceanography University grants

University training awards

Meteorological Office

Hydrological Research Unit

Grant aided laboratories

Administration

\begin{tabular}{|c|c|c|c|}
\hline $\mathrm{EI} \cdot 34 \mathrm{~m}$ & \multicolumn{3}{|c|}{25.60 per cent } \\
\hline$\$ 0.96 \mathrm{~m}$ & $18 \cdot 40$ & , , & ,, \\
\hline$£ 0.65 \mathrm{~m}$ & $12 \cdot 40$ &, & ,. \\
\hline$£ 0.68 \mathrm{~m}$ & $13 \cdot 04$ & , & \\
\hline $\mathrm{f} 0.44 \mathrm{~m}$ & $8 \cdot 33$ & , & \\
\hline $\mathrm{f} 0.08 \mathrm{~m}$ & $1 \cdot 46$ & , & \\
\hline$£ 0.08 \mathrm{~m}$ & $1 \cdot 45$ &. & . \\
\hline $\mathfrak{f} 0.70 \mathrm{x}$ & $13 \cdot 30$ & & \\
\hline$£ 0.17 \mathrm{~m}$ & $3 \cdot 32$ &, & \\
\hline
\end{tabular}

The main force of reorganization has so far been felt in the Institute of Geological Sciences (formerly the Geological Survey). Here a much wider research programme has been agreed, and the institute will be responsible for geological investigations of the continental shelf. The discovery of natural gas in the North Sea, and the increasing importance of the exploitation of sand and gravel, have stimulated this new development. During the summer of this year the first investigation was made, in the north Irish Sea, and preliminary work has also been done off Scotland and in the Moray Firth. There is a good chance that the institute will be moving out of London at some time in the future, although so far it has been impossible to find anywhere suitable. Difficulties of accommodation in London have proved "the most hampering factor for smooth progress during 1966" the report says, but the situation has been eased by the leasing of another building in Princes Gate, not far from the museum.

The Nature Conservancy has also undergone a complete reorganization since the coming of the council. The research has been regrouped into eight groups which the council has decided to call Habitat Teams. Each is responsible for a different habitat-Monks Wood Research Station looks after lowland grasslands and grass heaths, and wildlife in the agricultural environment, for example, while hill grasslands are the responsibility of the group at Bangor, and wetlands that of the group at Edinburgh. One of the council's principal preoccupations since the Torrey Canyon incident has been the study of coastal ecology, and this will be studied by the team at Furzebrook until the research station at Norwich is complete. One interesting conclusion reached by the Unit of Grouse and Moorland Ecology during the year was that grouse stocks can be considerably improved by burning small fires all over the grouse moors. The survey shows a direct correlation between the number of fires started and the grouse stocks, and the report suggests that by better management many of the Scottish grouse moors could be brought back to their former glory.
'The most fashionable part of the council's work is that in oceanography. The Ministry of Technology, the report says, "is concerned to identify technological developments which can make use of any spare capacity of the Atomic Energy Research Establishment (Harwell) that may arise in the near future". The report then goes on to suggest that the ministry is thinking of turning Harwell's attention towards the technology of the sea and the sea-bed, and that this was the reason for the conference on the subject at Harwell in April this year. But the report makes clear that it intends to remain the prime co-ordinator of marine scientific research in Britain and to encourage the ministry to plan the commercial exploitation of the research findings. In other words, if oceanography is to be promoted to a major research industry by the British Government, the council has no intention of being outmanoeuvred by Harwell. It is clear, though, that more research vessels are going to be needed; the council recommends that a new vessel primarily intended for biological research, and for use by the Scottish Marine Biological Association and the universities, should be built. The Institute of Geological Sciences will need a new dual-purpose vessel, again to be used in conjunction with the universities, and two smaller vessels will be needed for coastal work. Finally, the council has made provision for a two-man submersible, capable of operating at 100 fathoms, with a support vessel. It would be surprising if the development of just such a craft by a British firm (see Nature, last week, 216, 845; 1967) can have been entirely coincidental.

Apart from the ecology and geology of the coastline, and the geology of the continental shelf, the other major new development described in the report is in the hydrology and biology of inland waters. This will be done, the report says, by building up the Hydrological Research Unit so that it can carry out a comprehensive programme of research into all the factors affecting water balance in catchments, and develop an effective means of co-ordinating work in hydrology being done elsewhere. As if to demonstrate that this is more than a fine phrase, the council points out that the research effort of the unit has more than doubled since the council took over responsibility for it two years ago. And the council now intends to treble the present research effort by 1970 .

All this has not been done without a marked expansion of the administrative side of the council. When the report went to press the staff was some seventy-five, and since then a further expansion to almost 100 has occurred. As a result of this expansion, the council was forced to move out of its offices in State House, and has now taken over eight floors in Alhambra House in Charing Cross Road. Even this, however, seems to be barcly adequate for the council's purposes.

\section{Research for Industry}

The Ministry of Technology is to set up industrial units in British universities to help industry by providing commercial consultancy and research services. For a start, the units will be established in four universities, at the College of Aeronauties at Cranfield and at the Risley establishment of the Atomic Energy Authority. The ministry has made a launching grant of about $£ 1$ million to get the units started, on the condition that 
each appoints a full time manager to look after the commercial activities. Once the centres are operating successfully, it is expected that they will be self supporting, and the money will be freed to start new centres at other universities.

The first centres reflect the British Government's interest in tribology-the study of interacting surfaces in relative motion, including friction, wear and bearing design. The universities of Leeds and Swansea and the establishment at Risley will be concerned with tribology. The University of Strathclyde has a general brief covering the whole of engineering; Cranfield will look after precision engineering and Bangor will be responsible for instrumentation and control engineering. Each unit will be undertaking contract research for industry and the project is intended to be a thoroughly commercial one. But the ministry foresees no conflict between the units and the universities proper, and the minister himself goes near to saying that the commercial pressures will be a good thing for all concerned. "The universities are going to sell themselves to industry," Mr Benn declares.

In approving the centre at Risley, the minister seems implicitly to have rejected the recommendation of the Select Committee on Science and Technology, which reported last week. The committee said that the authority should not undertake work on subjects not inextricably linked with its primary task. Mr Benn said that the policy of diversification is "well estab. lished".

The emphasis on tribology, and the name, derive from a working party set up by Lord Bowden when he was Minister of State at the Department of Education and Science in 1964. The committee, under the chairmanship of $\mathrm{Mr} \mathrm{H}$. Peter Jost, was the originator of the now celebrated claim that industry could save $£ 500$ million a year by the better use of lubrication. In support of these figures, Mr Jost has quoted the experience of East Germany, where training in lubrication has been made compulsory, and qualified lubrication engineers have been appointed to state owned works. Within a few years, Mr Jost said, the East German steel industry has saved $£ 2-£ 3$ million, which would have meant $£ 21$ million in Britain. One of the conclusions of the Jost report was that inadequate training in tribology would be a major stumbling block-but Mr Benn's new proposals make no direct provision for this.

\section{Glass Reinforced Plastics}

A HAPPY accident in 1940 , when catalysed polyester resin was spilt over several layers of glass fibre, produced the first glass reinforced plastic (GRP). Since then the highly satisfactory structural properties of this material have been studied and it can now be considered alongside the more conventional building materials of concrete and steel. The development, properties and design qualities of glass reinforced polyester resins were described by Mr Brian J. Bell at a meeting of the Society of Engineers on December 4 .

Polyester resin has the great advantage of polymerizing at room temperature and low pressure. GRP can therefore be moulded (layed-up) by hand, and can be used for moulds of any size and shape. It is resistant to weather and many chemicals. These advantages are somewhat offset by the slowness of production compared with injection moulding methods, and skill is required to produce a material of consistent strength. Glass fibre for reinforcement and the resin itself are expensive, but no costly equipment is required for production of GRP. Fillers can be added which alter the gelation time, and mechanical, thixotropic and self-extinguishing properties of GRP and the form of reinforcement can also be chosen to suit the required design properties. The most common form of reinforcement is the chopped strand mat in which $2 \mathrm{in}$. random strands are bonded together with resin to form a mat which weighs from 1 to $2 \mathrm{oz}$. per square foot.

GRP can be produced by contact pressure and by low or high pressure moulding. Each method has variations which are introduced to suit the size, shape, dimensional tolerance, cost, strength and quantity of the required product. In all cases a release agent is required for releasing the product from the mould. Mr Bell gave examples of the general properties of various laminates that can be made from GRP, and compared its properties with those of mild steel. Volume by volume GRP can be almost twice as strong as mild steel, while weight for weight it can be thirteen times stronger. But sometimes it lacks rigidity, and variations can occur in mechanical properties because of differences in manufacturing conditions or in composition. Mr Bell described ways in which the limited span of GRP can be extended, particularly by folding the material-despite the unsolved problem of prestressing, GRP obviously has a great future.

\section{Another Food Supplement}

LAST week the American University of Beirut announced that a high protein food supplement, called "l'aubina", had been developed in Beirut under the direction of the Columbia University Institute of Nutrition Sciences and financed by the United States National Institutes of Health. It is the latest addition to the growing list of food supplements developed from local products in various parts of the world in an attempt to combat local malnutrition with locally grown produce. "L'aubina" is made from chick peas and parboiled wheat--both are grown in the Middle East, North Africa, India and Pakistan-with small amounts of bone ash and skim milk. It is easy to make--apparently any food manufacturer could make it with existing machinery-and cheap. In tests, the nutritional health of children was maintained by a daily supplement of 7 ounces of "l'aubina" which would cost only about $2 s$. 1d. (25 cents) to produce. It contains $17 \cdot 1$ per cent protein-about the same amount as roast leg of lamb-adequate amounts of vitamins $A$ and $D$ and some vitamin $B$ and calcium.

The question now is whether a commercial producer can be found to produce "l'aubina" in bulk and, even more important, whether it will be accepted by those who are suffering from malnutrition. Past experiences are not at all encouraging. In Peru, a supplement called "Peruvita", which is made from the local plant quinoa, was developed over a period of five years but abandoned last year because it was not accepted. Similarly in Guatemala, "Incaparina". made from cotton seed and sorghum, has not been accepted. It is still produced but only reaches 2 per cent of the children in the country. So great is the prejudice against these supplements that even 